\title{
Improvement in Carbonation Resistance of Portland Cement Mortar Incorporating $\gamma$-Dicalcium Silicate
}

\author{
Zhengxin Chen $\mathbb{D}^{1},{ }^{1}$ Yunsu Lee, ${ }^{1}$ Hyeongkyu Cho, ${ }^{2}$ Hanseung Lee, ${ }^{3}$ and Seungmin Lim $\mathbb{D i D}^{3}$ \\ ${ }^{1}$ Department of Architectural System Engineering, Hanyang University, Seoul, Republic of Korea \\ ${ }^{2}$ Korea Institute of Ceramic Engineering and Technology, Icheon, Republic of Korea \\ ${ }^{3}$ Department of Architectural Engineering, Hanyang University, Seoul, Republic of Korea \\ Correspondence should be addressed to Seungmin Lim; smlim09@hanyang.ac.kr
}

Received 29 January 2019; Revised 22 April 2019; Accepted 20 June 2019; Published 5 August 2019

Academic Editor: Viviana F. Rahhal

Copyright (c) 2019 Zhengxin Chen et al. This is an open access article distributed under the Creative Commons Attribution License, which permits unrestricted use, distribution, and reproduction in any medium, provided the original work is properly cited.

\begin{abstract}
In this study, $\gamma$-dicalcium silicate $\left(\gamma-\mathrm{C}_{2} \mathrm{~S}\right)$ was incorporated into ordinary Portland cement (OPC) to sequester $\mathrm{CO}_{2}$ to enhance the carbonation resistance of cement-based composite materials. $\gamma-\mathrm{C}_{2} \mathrm{~S}$ can react with $\mathrm{CO}_{2}$ rapidly to form vaterite and high dense $\mathrm{SiO}_{2}$ gel which could block the pores off and then inhibit further diffusion of $\mathrm{CO}_{2}$ into the system. Cement mortar specimens containing $0 \%, 5 \%, 10 \%, 20 \%$, and $40 \% \gamma-\mathrm{C}_{2} \mathrm{~S}$ as cement replacement were prepared. After water curing for 28 days followed by curing in an environmental chamber for 28 days, the specimens were then exposed to an accelerated carbonation with $5 \% \mathrm{CO}_{2}$ concentration for 28 days. The carbonation depth of the cement mortar with a low replacement rate (5\% and $10 \%)$ was lower than that of the OPC mortar at all ages due to the sequestration of $\mathrm{CO}_{2}$ by $\gamma-\mathrm{C}_{2} \mathrm{~S}$. However, the cement mortar with a high replacement rate $(20 \%$ and $40 \%)$ showed less carbonation resistance due to the dilution effect of $\gamma-\mathrm{C}_{2} \mathrm{~S}$ replacement and increase in initial porosity caused by nonhydraulic characteristic of $\gamma-\mathrm{C}_{2} \mathrm{~S}$.
\end{abstract}

\section{Introduction}

Carbonation is an important factor affecting the service life of reinforced concrete structures. Carbonation of concrete occurs when $\mathrm{CO}_{2}$ in the air continuously traverses capillary pores, diffuses into concrete, dissolves in the pore solution, and forms carbanions that react with the hydration products to form calcium carbonates. The carbonation reaction reduces the $\mathrm{pH}$ value inside the concrete to a value low enough to break the protective film on the surface of steel reinforcement. Thus, the corrosion of steel bars is induced [1-4].

In order to extend the service life of reinforced concrete buildings which can be damaged by carbonation, several factors must be considered during the design stage, such as structural aspects, material selection, concrete mix design, proper compaction, and correct curing [5]. The application of coatings is also adopted in practical operations [6-9]. These methods aim to reduce the contact of $\mathrm{CO}_{2}$ with concrete by improving pore structure to reduce channels for the diffusion of $\mathrm{CO}_{2}$ or shielding the concrete surface. Unlike conventional methods, the approach proposed in this study attempts to inhibit the diffusion of $\mathrm{CO}_{2}$ by introducing a highly active $\mathrm{CO}_{2}$-capturable material, $\gamma$ - $\mathrm{C}_{2} \mathrm{~S}$, into concrete to fix up $\mathrm{CO}_{2}$ present in the concrete, which could reduce $\mathrm{CO}_{2}$ diffusion rate. During the reaction between $\mathrm{CO}_{2}$ and $\gamma-\mathrm{C}_{2} \mathrm{~S}$, carbonation products with large molecular weights are formed $[10,11]$, which could block the capillary pores. Then, the permeability of cement-based composite materials can be reduced; thus, the available channels for the subsequent intrusion of $\mathrm{CO}_{2}$ are reduced, and the carbonation reactions can be further limited [12].

$\gamma-\mathrm{C}_{2} \mathrm{~S}$ has an orthorhombic structure, which is called calcio-olivine. Olivine group minerals have become a popular subject of research for $\mathrm{CO}_{2}$ storage and capture (CSC) due to their high $\mathrm{CO}_{2}$ sequestration per unit mass capabilities $[12,13] . \gamma-\mathrm{C}_{2} \mathrm{~S}$ is considered as an insoluble substance, but it can rapidly react with $\mathrm{CO}_{2}[14,15]$ to form calcium carbonates and highly polymerized silica gel. 


$$
\begin{gathered}
\mathrm{CO}_{2}+\mathrm{H}_{2} \mathrm{O} \longrightarrow \mathrm{H}_{2} \mathrm{CO}_{3} \\
2 \mathrm{CaO} \cdot \mathrm{SiO}_{2}+2 \mathrm{H}_{2} \mathrm{CO}_{3} \longrightarrow 2 \mathrm{CaCO}_{3}+\mathrm{SiO}_{2} \text { gel like }
\end{gathered}
$$

The carbonation reaction of $\gamma-\mathrm{C}_{2} \mathrm{~S}$ is as follows.

Although $\gamma-\mathrm{C}_{2} \mathrm{~S}$ does not react with water directly, it is the necessary reaction medium for the carbonation of $\gamma-C_{2} S$. Similar with other olivine group minerals, $\gamma-\mathrm{C}_{2} \mathrm{~S}$ reacts with $\mathrm{CO}_{2}$ after the formation of a very thin water film on the surface of particles [16]. In Kerisi's study, it was confirmed that $\gamma-C_{2} \mathrm{~S}$ had the strongest water absorption capacity than the other four different types of olivine group minerals [17]. Additionally, different from the carbonation mechanism of other calcium silicates, such as $\mathrm{C}_{3} \mathrm{~S}$ and $\beta-\mathrm{C}_{2} \mathrm{~S}$, which have a hydrate activity, very few $\mathrm{Ca}$ ions of $\gamma-\mathrm{C}_{2} \mathrm{~S}$ are dissolved in water, so the intermediate product, such as $\mathrm{Ca}(\mathrm{OH})_{2}$, is not formed during carbonation [18]. The direct reaction between $\gamma-\mathrm{C}_{2} \mathrm{~S}$ and $\mathrm{CO}_{2}$ also results in a high carbonation reaction rate. Theoretically, $1 \mathrm{~g}$ of $\gamma-\mathrm{C}_{2} \mathrm{~S}$ can react with $0.5 \mathrm{~g}$ of $\mathrm{CO}_{2}$ [19].

Several novel $\gamma-\mathrm{C}_{2} \mathrm{~S}$ based cementitious materials have been developed by using the high carbonation activity of $\gamma-C_{2}$ S. In the literature of Higuchi et al. [19], a new type of concrete $\left(\mathrm{CO}_{2}\right.$-SUICOM) has been proposed. Fly ash and $\gamma-\mathrm{C}_{2} \mathrm{~S}$ are mixed into concrete to replace cement, and concrete samples were cured in the exhaust gas treatment room of power plant which is filled with exhaust gas containing a $15 \%-20 \%$ concentration of $\mathrm{CO}_{2}$. Concrete samples had a compressive strength of $21.0 \mathrm{~N} / \mathrm{mm}^{2}$ after carbonation which is close to that of control group without $\gamma-\mathrm{C}_{2} \mathrm{~S}$. Guan et al. developed a $\gamma-\mathrm{C}_{2} \mathrm{~S}$ based mortar using $\mathrm{CO}_{2}$ curing. By increasing the concentration of $\mathrm{CO}_{2}$ to $99.99 \%$, the compressive strength of $\gamma-\mathrm{C}_{2} \mathrm{~S}$ mortar samples can reach up to $60 \mathrm{MPa}$ in 5 hours.

However, the application of $\gamma-\mathrm{C}_{2} \mathrm{~S}$ has not been implemented on a large scale yet. The $\mathrm{CO}_{2}$ emissions during the manufacturing of $\gamma-\mathrm{C}_{2} \mathrm{~S}$ using existing methods are lower than those of OPC [20]. From the perspective of mitigating the greenhouse effect, the application of $\gamma-\mathrm{C}_{2} \mathrm{~S}$ in the construction industry has a great research value. In this study, the beneficial effects of $\gamma-\mathrm{C}_{2} \mathrm{~S}$ on the carbonation resistance of cement-based composite materials are investigated. The macroscopic and microscopic properties, such as pore structure, carbonation depth, and calcium carbonate content, of cement mortar and cement paste containing $\gamma-\mathrm{C}_{2} \mathrm{~S}$ with and without carbonation were studied.

\section{Materials and Methods}

\subsection{Materials}

2.1.1. Synthesis of $\gamma-C_{2} S$. The $\gamma-C_{2} S$ used in this study was prepared by using analytical grade $\mathrm{Ca}(\mathrm{OH})_{2}$ and $\mathrm{SiO}_{2}$ powders. Powders were mixed in a $\mathrm{Ca} / \mathrm{Si}$ ratio of $2: 1$ and then placed in a muffle furnace for calcination. The heating rate was set at $10^{\circ} \mathrm{C} / \mathrm{min}$, and the temperature was maintained at $1450^{\circ} \mathrm{C}$ for 1.5 hours. After calcining, the samples were cooled down to room temperature with the cooling rate at $60^{\circ} \mathrm{C} / \mathrm{min}$, which is close to the natural cooling rate [20]. During the cooling process, the conversion from $\beta-\mathrm{C}_{2} \mathrm{~S}$ to
$\gamma-\mathrm{C}_{2} \mathrm{~S}$ results in volume expansion, followed by pulverization of the materials, which is known as the "dusting phenomenon" [21]. X-ray diffraction (XRD) was performed for the phase identification and quantification of the synthetic $\gamma-\mathrm{C}_{2} \mathrm{~S}$ sample. RIGAKU D/MAX-2500 was used with $\mathrm{CuK} \alpha$ radiation of $100 \mathrm{~mA}$ and $40 \mathrm{kV}$. XRD results for synthetic $\gamma-\mathrm{C}_{2} \mathrm{~S}$ after performing Rietveld refinement using the software Profex are shown in Figure 1. The purity of $\gamma-\mathrm{C}_{2} \mathrm{~S}$ is greater than $90 \%$. The chemical composition of synthetic $\gamma-\mathrm{C}_{2} \mathrm{~S}$ was characterized by X-ray fluorescence (XRF), and the result is shown in Table 1 . Synthetic $\gamma-C_{2} S$ was sieved through a $150 \mu \mathrm{m}$ sieve before use.

2.1.2. Sample Preparation and Curing Method. Type 1 ordinary Portland cement (OPC) was used in this study, and its chemical composition is listed in Table 2. Both cement mortar and cement paste specimens have a water-to-binder ratio of 0.5 . As shown in Table 3, cement paste mixtures are designated as OPC-P, $\gamma 5-\mathrm{P}, \gamma 10-\mathrm{P}, \gamma 20-\mathrm{P}$, and $\gamma 40-\mathrm{P}$, which contain $0 \%, 5 \%, 10 \%, 20 \%$, and $40 \% \gamma-\mathrm{C}_{2}$ S replacement, respectively. The cement mortar specimens have a binderto-sand ratio of $1: 3$. Cement mortar mixtures are designated as OPC-M, $\gamma 5-\mathrm{M}, \gamma 10-\mathrm{M}, \gamma 20-\mathrm{M}$, and $\gamma 40-\mathrm{M}$, which contain $0 \%, 5 \%, 10 \%, 20 \%$, and $40 \% \gamma-\mathrm{C}_{2} \mathrm{~S}$ replacement, respectively. Cement mortar specimens and cement paste specimens were prepared according to KS L 5109 and then cast into a $4 \times 4 \times 16 \mathrm{~cm}$ and $3.5 \times 3.5 \times 1 \mathrm{~cm}$ plastic mold, respectively.

Both cement paste and mortar specimens were demolded after 24 hours. After demolding, specimens were placed in tap water for 27 days and were then dried in a constant temperature chamber (relative humidity 60\%, temperature $20^{\circ} \mathrm{C}$ ) for 28 days. After that, cement mortar specimens and a portion of the specimens was moved into a $\mathrm{CO}_{2}$ chamber (relative humidity $60 \%, \mathrm{CO}_{2} 5 \%$, and temperature $20^{\circ} \mathrm{C}$ ) for the accelerated carbonation curing over 28 days, and the remainder of the specimens were left in the environmental chamber. Curing process and characterizations used in this study are summarized in Table 4.

\subsection{Test Methods}

2.2.1. Hydration Product Analysis. To confirm the hydration products of the cement-based materials containing $\gamma-\mathrm{C}_{2} \mathrm{~S}$ subjected to or not subjected to accelerated carbonation, the cement paste specimens were ground into powder with a particle size less than $150 \mu \mathrm{m}$ at 84 days, and the powders were analyzed by XRD and Fourier-transform infrared spectroscopy (FT-IR). FT-IR was performed using a PerkinElmer Spectrum Two FT-IR spectrometer (L160000A). Spectral analysis was performed over the range 4000$400 \mathrm{~cm}^{-1}$ at a resolution of $4 \mathrm{~cm}^{-1}$.

\subsubsection{Quantification of Calcium Carbonate. Calcium car-} bonate content of carbonated cement paste was evaluated based on the results of thermogravimetry analysis (TGA). Each batch of cement paste specimens was ground to into 


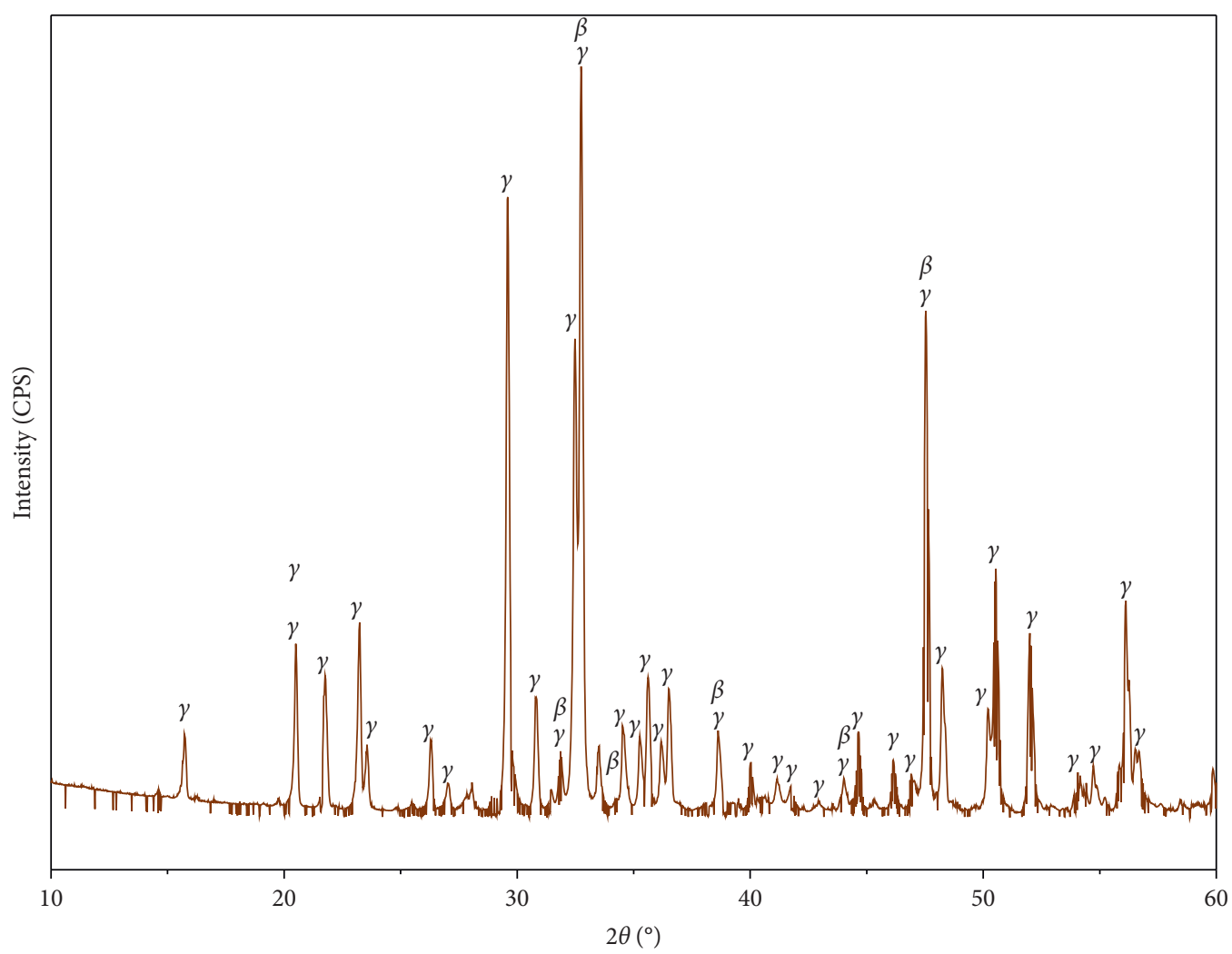

FIGURE 1: XRD results of synthetic $\gamma-\mathrm{C}_{2} \mathrm{~S}\left(\gamma: \gamma-\mathrm{C}_{2} \mathrm{~S} ; \beta\right.$ : $\left.\beta-\mathrm{C}_{2} \mathrm{~S}\right)$.

TABLe 1: Chemical composition of synthetic $\gamma-C_{2} S$ (weight (\%)).

\begin{tabular}{lcccccc}
\hline $\mathrm{CaO}$ & $\mathrm{SiO}_{2}$ & $\mathrm{Al}_{2} \mathrm{O}_{3}$ & $\mathrm{Fe}_{2} \mathrm{O}_{3}$ & $\mathrm{MgO}$ & $\mathrm{SO}_{3}$ & $\mathrm{SrO}$ \\
\hline 63.58 & 35.55 & 0.09 & 0.23 & 0.36 & 0.05 & 0.097 \\
\hline
\end{tabular}

TABle 2: Chemical composition of OPC (weight (\%)).

\begin{tabular}{lccccc}
\hline $\mathrm{CaO}$ & $\mathrm{SiO}_{2}$ & $\mathrm{Al}_{2} \mathrm{O}_{3}$ & $\mathrm{Fe}_{2} \mathrm{O}_{3}$ & $\mathrm{SO}_{3}$ & $\mathrm{MgO}$ \\
\hline 65.14 & 18.02 & 3.04 & 3.08 & 4.24 & 2.95 \\
\hline
\end{tabular}

TABle 3: Mix proportions of cement paste specimens and cement mortar specimens.

\begin{tabular}{lcccc}
\hline Samples & $\begin{array}{c}\text { Binder (weight } \\
(\%))\end{array}$ & $\begin{array}{c}\text { Sand-to-binder } \\
\text { ratio }\end{array}$ & $\begin{array}{c}\text { Water-to-binder } \\
\text { ratio }\end{array}$ \\
\hline OPC-P & 100 & 0 & 0 & \\
$\gamma 5-\mathrm{P}$ & 95 & 5 & 0 & \\
$\gamma 10-\mathrm{P}$ & 90 & 10 & 0 & \\
$\gamma 20-\mathrm{P}$ & 80 & 20 & 0 & \\
$\gamma 40-\mathrm{P}$ & 60 & 40 & 0 & \\
OPC-M & 100 & 0 & 3 & \\
$\gamma 5-\mathrm{M}$ & 95 & 5 & 3 & \\
$\gamma 10-\mathrm{M}$ & 90 & 10 & 3 & \\
$\gamma 20-\mathrm{M}$ & 80 & 20 & 3 & \\
$\gamma 40-\mathrm{M}$ & 60 & 40 & 3 & \\
\hline
\end{tabular}

powder with a particle size less than $150 \mu \mathrm{m}$ at 84 days. Powders were heated from room temperature to $1000^{\circ} \mathrm{C}$ at a heating rate of $10^{\circ} \mathrm{C} / \mathrm{min}$ under a continuous flow of $\mathrm{N}_{2}$ gas.
2.2.3. Carbonation Depth Measurement. Cement mortar specimens were sealed with epoxy resin except for two opposite rectangular faces at the age of 54 days. After drying for 2 days, the test specimens were placed in a $\mathrm{CO}_{2}$ chamber (relative humidity $60 \%, \mathrm{CO}_{2} 5 \%$, and temperature $20^{\circ} \mathrm{C}$ ) for the accelerated carbonation. The sealed specimens were cut perpendicular to the unsealed surfaces after $3,7,14$, and 28 days of accelerated carbonation. The carbonation depth was measured by using a $1 \%$ phenolphthalein $\mathrm{pH}$ indicator. For each set, three specimens of each age were used for carbonation depth measurement. For each specimen, 12 carbonation depth data were obtained, and the average value was calculated as the carbonation depth.

2.2.4. Pore Structure Analysis. Mercury intrusion porosimetry (MIP) was performed to study changes in pore structure of the cement mortar after accelerated carbonation. The pore structure of each test piece was measured and analyzed by Micromeritics AutoPore IV 9500 mercury intrusion porosimeter (MIP). The pore diameter measurement in this study is 0.003 to $370 \mu \mathrm{m}$.

\section{Results and Discussion}

3.1. XRD Analysis. Crystalline phases in the specimens with and without accelerated carbonation were analyzed by XRD, and the results are shown in Figures 2 and 3.

The diffraction peaks of the major hydration products, such as $\mathrm{Ca}(\mathrm{OH})_{2}$ and ettringite, can be observed in Figure 2. 
TABLE 4: The curing process and characterizations of the samples.

\begin{tabular}{|c|c|c|c|}
\hline & Accelerated carbonation experiment (curing process) & Characterizations & Samples \\
\hline \multirow{10}{*}{ Cement paste } & \multirow{5}{*}{ X (28-day water curing + 56-day air curing) } & \multirow{5}{*}{ XRD FT-IR } & OPC-P \\
\hline & & & $\gamma 5-\mathrm{P}$ \\
\hline & & & $\gamma 10-\mathrm{P}$ \\
\hline & & & $\gamma 20-\mathrm{P}$ \\
\hline & & & $\gamma 40-\mathrm{P}$ \\
\hline & \multirow{5}{*}{$\begin{array}{l}\text { O (28-day water curing }+28 \text {-day air curing }+28 \text {-day } \\
\text { accelerated carbonation })\end{array}$} & \multirow{5}{*}{ XRD FT-IR DSC-TG } & OPC-PC \\
\hline & & & $\gamma 5-\mathrm{PC}$ \\
\hline & & & $\gamma 10-\mathrm{PC}$ \\
\hline & & & $\gamma 20-\mathrm{PC}$ \\
\hline & & & $\gamma 40-\mathrm{PC}$ \\
\hline \multirow{11}{*}{ Cement mortar } & \multirow{11}{*}{$\begin{array}{c}\text { O (28-day water curing }+28 \text {-day air curing }+28 \text {-day } \\
\text { accelerated carbonation })\end{array}$} & \multirow{3}{*}{ Mercury intrusion porosimetry (MIP) } & OPC-M \\
\hline & & & $\gamma 10-\mathrm{M}$ \\
\hline & & & $\gamma 40-\mathrm{M}$ \\
\hline & & \multirow{5}{*}{ Carbonation depth } & OPC-MC \\
\hline & & & $\gamma 5-\mathrm{MC}$ \\
\hline & & & $\gamma 10-\mathrm{MC}$ \\
\hline & & & $\gamma 20-\mathrm{MC}$ \\
\hline & & & $\gamma 40-\mathrm{MC}$ \\
\hline & & \multirow{3}{*}{ MIP } & OPC-MC \\
\hline & & & $\gamma 10-\mathrm{MC}$ \\
\hline & & & $\gamma 40-\mathrm{MC}$ \\
\hline
\end{tabular}

At the same time, some diffraction peaks of quartz were also observed. The diffraction peaks of $\gamma-\mathrm{C}_{2} \mathrm{~S}$ also appeared obviously at $20.5^{\circ}, 22^{\circ}, 32^{\circ}$, and $55^{\circ}$ of $2 \theta$ for $\gamma 20$-PC and $\gamma 40$-PC. In particular, it was found that the main diffraction peaks of $\mathrm{Ca}(\mathrm{OH})_{2}$ were reduced due to the decrease in the formation of $\mathrm{Ca}(\mathrm{OH})_{2}$ by the large replacement of cement for $\gamma 40-\mathrm{PC}$; meanwhile, the diffraction peaks of $\gamma-\mathrm{C}_{2} \mathrm{~S}$ became very conspicuous. In addition, since the analyzed powder samples were placed in the air and reacted with $\mathrm{CO}_{2}$, resulting in the formation of $\mathrm{CaCO}_{3}$, the diffraction peaks of calcite and vaterite were also detected.

The diffraction peaks of $\mathrm{Ca}(\mathrm{OH})_{2}$ were absent in all five batches of carbonated cement paste samples, and the diffraction peaks of three phases of $\mathrm{CaCO}_{3}$, calcite, aragonite, and vaterite, can be observed. Calcite was the main calcium carbonate phase formed in all specimens. Vaterite is considered to be the main carbonation product of $\gamma-\mathrm{C}_{2} \mathrm{~S}$. Saito reported that the crystallinity of $\mathrm{C}_{2} \mathrm{~S}$ is associated with the crystallinity of the carbonation products [18]. $\gamma-\mathrm{C}_{2} \mathrm{~S}$ and vaterite have a similar crystalline structure in which $\mathrm{Ca}^{2+}$ ions occupy a six-coordinate position of hexagonally close packed $\mathrm{O}^{2-}$, and their $\mathrm{Ca}-\mathrm{O}$ bond lengths are also similar. Table 5 shows the coordination number and $\mathrm{Ca}-\mathrm{O}$ bond length in $\mathrm{C}_{2} \mathrm{~S}$ and $\mathrm{CaCO}_{3}$ crystals $[12,22,23]$. Therefore, vaterite could be generated after the topotactic reaction of $\gamma-\mathrm{C}_{2} \mathrm{~S}$ in the carbonation reaction process [24]. So, the diffraction peaks of calcite are reduced for the cement paste mixed with $\gamma-\mathrm{C}_{2} \mathrm{~S}$. In addition, some previous studies reported that the main carbonation products of $\gamma-\mathrm{C}_{2} \mathrm{~S}$ are calcite $[15,25]$. This is because that calcite is more thermodynamically stable than the other two structures at room temperature and atmospheric pressure, aragonite is slightly less stable under similar conditions and is eventually transformed to calcite, and vaterite is thermodynamically the most unstable of the three crystal structures and can transform into the calcite at low temperature. Therefore, the different experimental environments and ways of preserving samples can cause a conversion of polymorphs in this study [26-30]. The diffraction peaks of quartz can be observed at approximately $26.5^{\circ}$ in the XRD results of all cement pastes, especially in carbonated samples of OPC which was very sharp. The quartz in samples might come from the clinker of the cement and/or synthetic $\gamma-\mathrm{C}_{2} \mathrm{~S}$ [31].

3.2. FT-IR Analysis. The FT-IR spectra of noncarbonated and carbonated cement paste at 84 days are shown in Figure 4. The shapes of the FT-IR spectra of the noncarbonated specimens were substantially similar because the hydration products in the specimens were the same, which is consistent with the XRD results. The noncarbonated samples show weak peak at $3640 \mathrm{~cm}^{-1}$, which corresponds to $\mathrm{H}-\mathrm{O}$ stretching vibrations of $\mathrm{Ca}(\mathrm{OH})_{2}$. The peak near $950 \mathrm{~cm}^{-1}$ corresponds to the $\mathrm{Q}^{2}$ vibration of the $v_{2} \mathrm{Si}-\mathrm{O}$ bond in the hydrate product-C-S-H $[32,33]$. The calcium carbonate formed by the reaction of the powdered specimen with $\mathrm{CO}_{2}$ in air is also reflected in the FT-IR spectra. The peaks at approximately $1400 \mathrm{~cm}^{-1}$ correspond to the asymmetric stretching vibration of $v_{3} \mathrm{C}-\mathrm{O}$ from three polymorphs of calcium carbonate (calcite, vaterite, and aragonite). Also, the peaks at $870 \mathrm{~cm}^{-1}$ and $850 \mathrm{~cm}^{-1}$ were assigned to the out-ofplane bending vibration of $v_{2} \mathrm{C}-\mathrm{O}$ from calcite and vaterite, respectively. The peaks observed at $715 \mathrm{~cm}^{-1}$ were caused by the in-plane bending vibration of $v_{4} \mathrm{C}$-O from calcite and aragonite [27-29, 34, 35].

In the FT-IR spectra of the carbonated specimens, the effect of carbonation can be clearly observed. Due to carbonation of $\mathrm{Ca}(\mathrm{OH})_{2}$, peaks of $\mathrm{O}-\mathrm{H}$ stretching vibrations were absent at $3640 \mathrm{~cm}^{-1}$. The peaks at approximately $1400 \mathrm{~cm}^{-1}, 870 \mathrm{~cm}^{-1}, 850 \mathrm{~cm}^{-1}$, and $715 \mathrm{~cm}^{-1}$ were sharper 


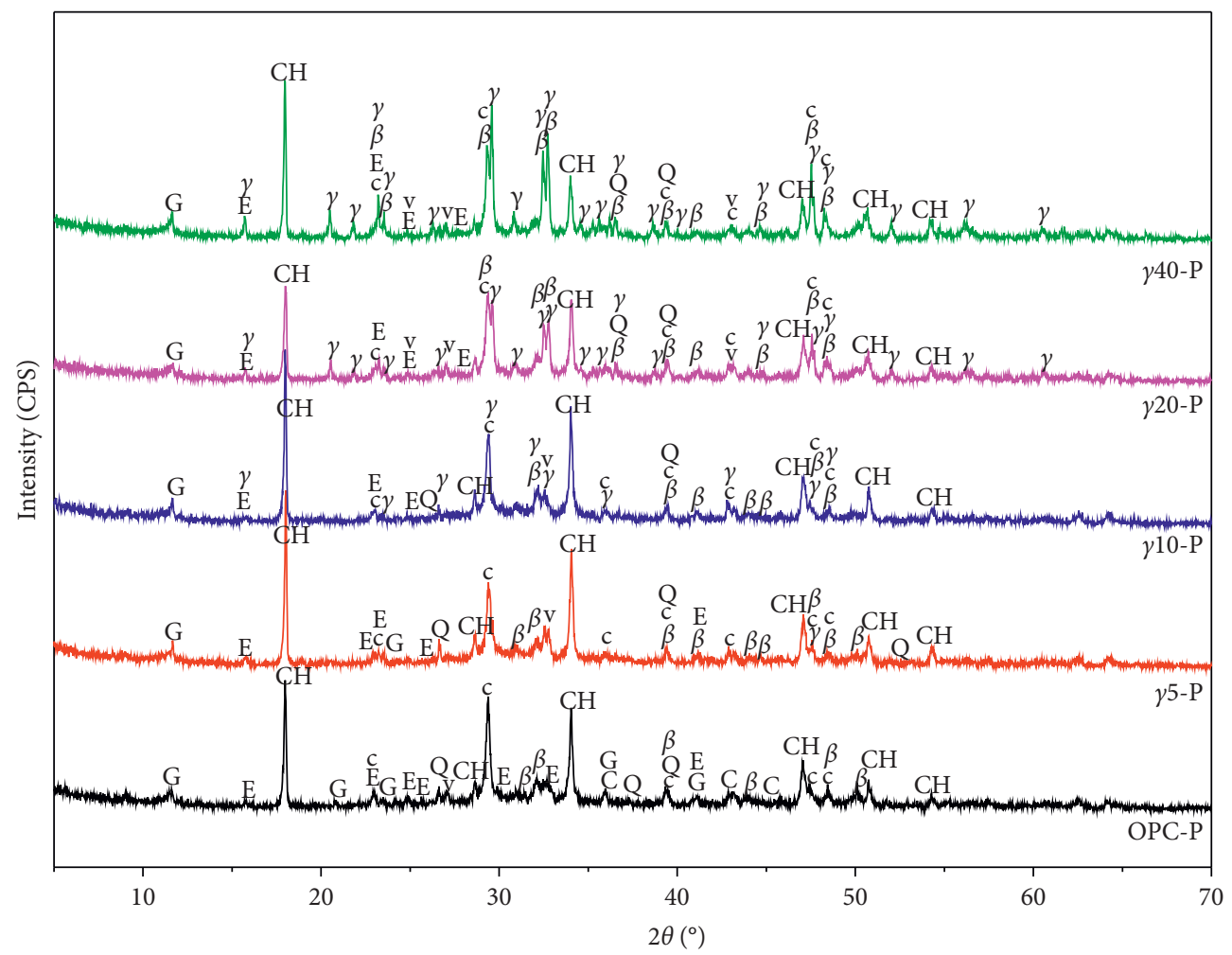

FIGURE 2: The XRD results of noncarbonated cement paste samples (P) after 84 days (E: ettringite; $\mathrm{CH}$ : portlandite; G: gypsum; Q: quartz; $\gamma$ : $\gamma-\mathrm{C}_{2} \mathrm{~S} ; \beta$ : $\beta-\mathrm{C}_{2} \mathrm{~S}$; C: calcite; A: aragonite; V: vaterite).

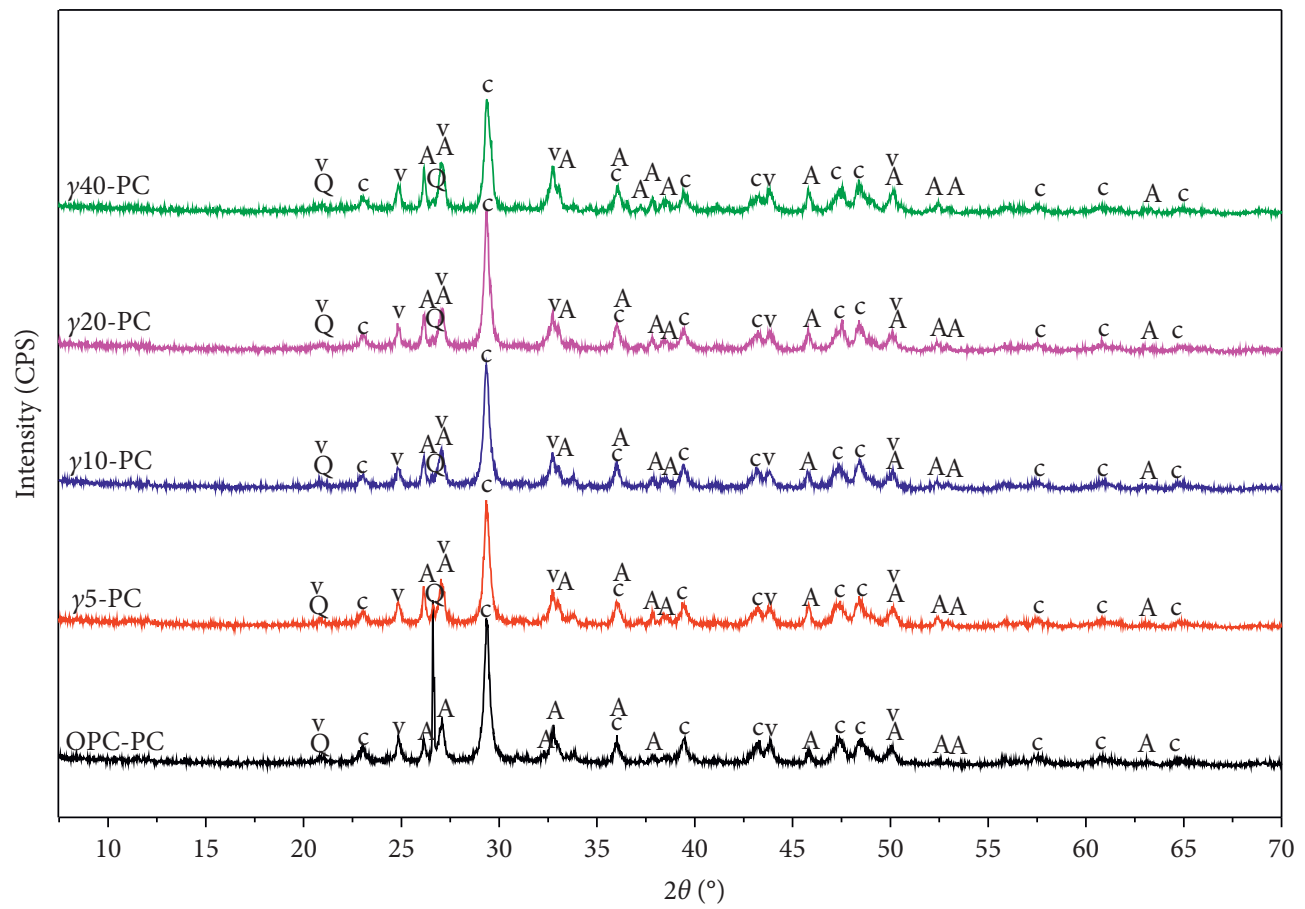

FIGURE 3: The XRD results of carbonated cement paste samples (PC) at 84 days (Q: quartz; C: calcite; A: aragonite; V: vaterite).

and more visible in comparison with noncarbonated samples. Lower crystallinity calcium carbonate formed during the accelerated carbonation, which was verified by the appearance of broad asymmetrical peaks at approximately
$1410 \mathrm{~cm}^{-1}$. Additionally, the appearance of new peaks was observed at $745 \mathrm{~cm}^{-1}$, which is attributed to the formation of vaterite $[24,27,28]$. For carbonated OPC specimens, the vaterite peak can be also observed because the carbonation of 
TABle 5: Coordination number and Ca-O bond length in $\mathrm{C}_{2} \mathrm{~S}$ and $\mathrm{CaCO}_{3}$ crystals $[12,22,23]$.

\begin{tabular}{lccccc}
\hline Parameter & $\gamma-\mathrm{C}_{2} \mathrm{~S}$ & $\beta-\mathrm{C}_{2} \mathrm{~S}$ & Vaterite & Calcite & Aragonite \\
\hline Coordinate number of $\mathrm{Ca}$ & 6 & $6 / 8$ & 6 & 6 & 9 \\
Average length of $\mathrm{Ca}-\mathrm{O}$ & 0.237 & 0.246 & 0.229 & 0.34 & 0.253 \\
\hline
\end{tabular}

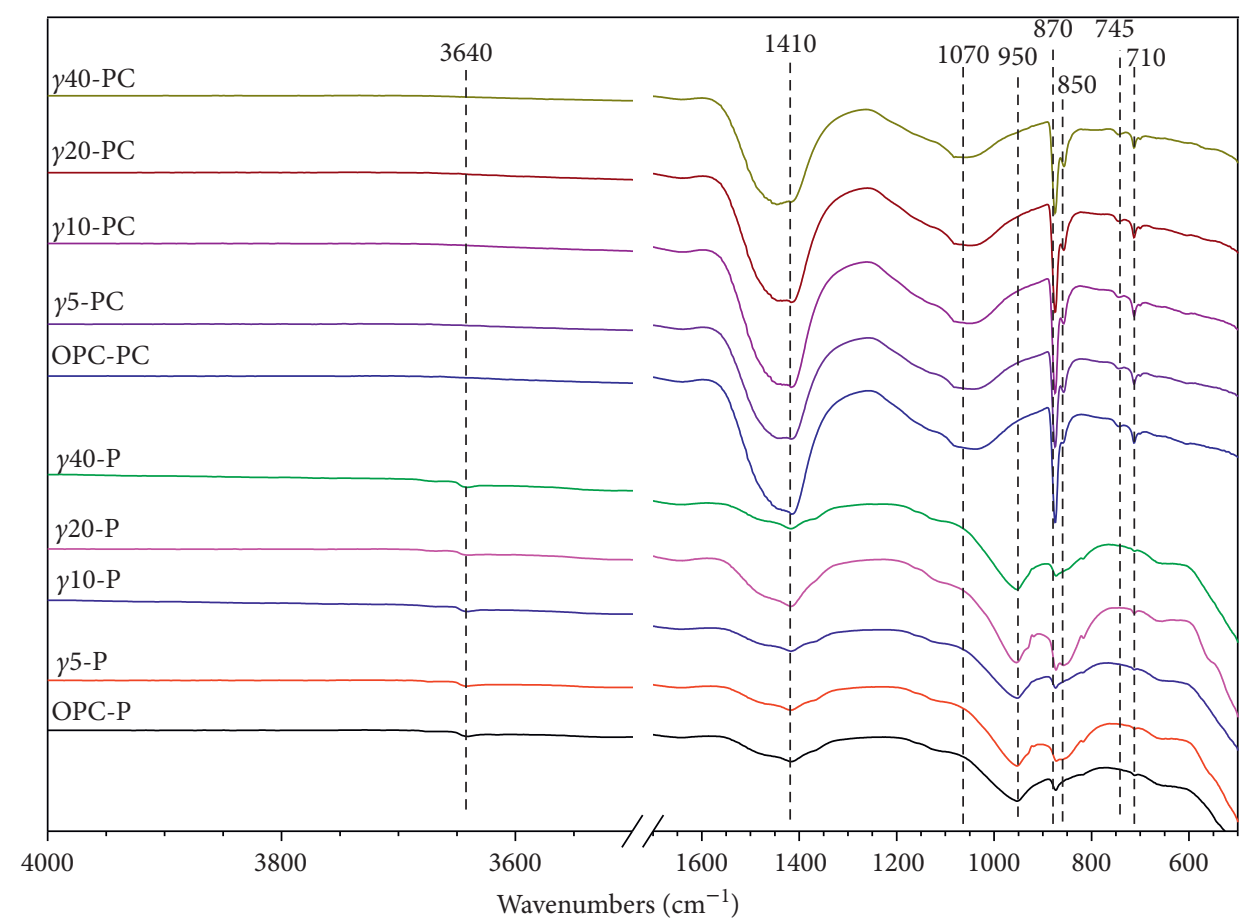

FIgURE 4: The FT-IR spectra of noncarbonated cement paste samples (P) and carbonated cement paste samples (PC) at 84 days.

C-S-H could form vaterite [2]. After the accelerated carbonation, the peaks of the Si-O-Si band that appeared in the FT-IR spectrum of the noncarbonated specimens at approximately $950 \mathrm{~cm}^{-1}$ appeared at approximately $1070 \mathrm{~cm}^{-1}$ in carbonated specimens. It indicates the formation of a silicate gel caused by the decalcification of C-S-H during the carbonation [36, 37].

3.3. TGA Analysis. To quantify the $\mathrm{CaCO}_{3}$ content of carbonated cement paste specimens, the completely carbonated cement paste specimens (confirmed by $1 \%$ phenolphthalein solution) were ground into powder and measured by using TGA. The differential thermogravimetry (DTG) and TG behaviors of each sample are shown in Figure 5.

Figure 5(b) shows that all specimens show very similar results of TG-DTG, which indicate the reaction products were almost same. All samples showed a mass loss at approximately $100^{\circ} \mathrm{C}$ due to the decomposition of free water and/or physically adsorbed water from C-S- $\mathrm{H}$ and/or $\mathrm{SiO}_{2}$ gel [38]. The humps in the region of $500^{\circ} \mathrm{C}-650^{\circ} \mathrm{C}$ and $650^{\circ} \mathrm{C}-750^{\circ} \mathrm{C}$ are due to the decomposition of poorly crystallized $\mathrm{CaCO}_{3}$. Sharp peaks at the temperature between $750^{\circ} \mathrm{C}$ and $850^{\circ} \mathrm{C}$ were attribute to the decomposition of well crystallized $\mathrm{CaCO}_{3}[35,39]$. In previous studies, researchers considered the mass loss at $750^{\circ} \mathrm{C}-850^{\circ} \mathrm{C}$ was from the decomposition of three polymorphs-calcite, vaterite, and aragonite. Based on these, we consider that the mass loss between $500^{\circ} \mathrm{C}$ and $850^{\circ} \mathrm{C}$ is mostly due to the decomposition of calcium carbonates of varying crystallinity [40]. Therefore, the mass loss in this range can be approximated as the amount of $\mathrm{CO}_{2}$ fixation by the cement paste specimens during the accelerated carbonation. According to Figure 5(a), the mass loss between $500^{\circ} \mathrm{C}$ and $850^{\circ} \mathrm{C}$ was calculated and are shown in Table 6. The $\mathrm{CaCO}_{3}$ content was calculated using formula (2) [41], and the results are shown in Table 7. It can be seen that the $\mathrm{CaCO}_{3}$ content of the samples mixed with $\gamma-\mathrm{C}_{2} \mathrm{~S}$ is slightly higher than that of OPC-PC, and the $\mathrm{CaCO}_{3}$ content increases with increases in the substitution ratio of $\gamma-\mathrm{C}_{2} \mathrm{~S}$, which is attributed to the high carbonation activity of $\gamma-\mathrm{C}_{2}$ S.where WL refers to the percent mass loss associated with the decomposition of subscript phase in TGA and MW refers to the molecular weight of subscript phase.

$$
\mathrm{CaCO}_{3}(\%)=\mathrm{WL}_{\mathrm{CaCO}_{3}}(\%) \times \frac{\mathrm{MW}_{\mathrm{CaCO}_{3}}}{\mathrm{MW}_{\mathrm{CO}_{2}}}
$$

3.4. Pore Structure Analysis. The pore size distribution and total porosity of cement mortar specimens at 84 days are shown in Figures 6 and 7, respectively. In Figure 6(a), it can 


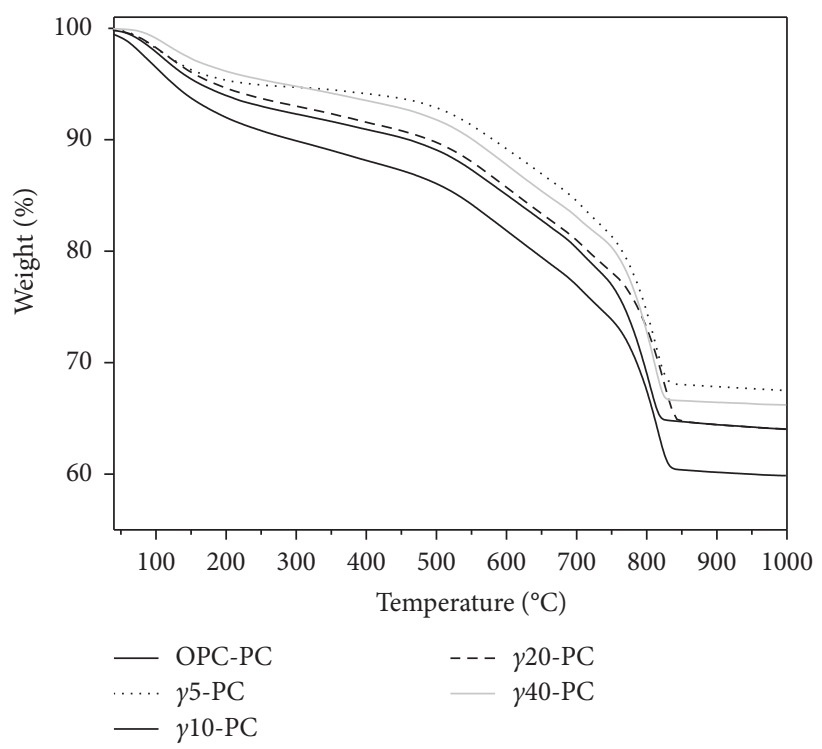

(a)

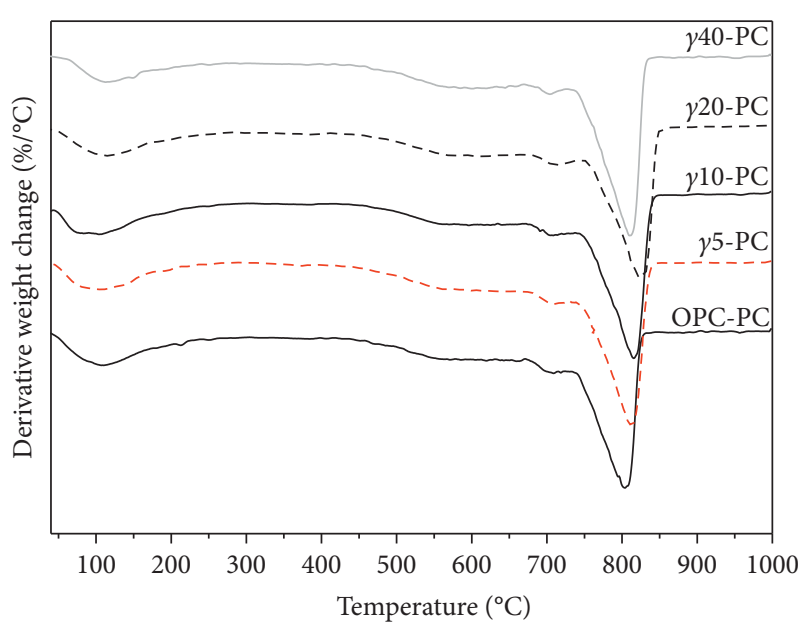

(b)

Figure 5: (a) TGA results of carbonated cement paste samples (PC) at 84 days. (b) DTG results of carbonated cement paste samples (PC) at 84 days.

TABle 6: Estimated $\mathrm{CO}_{2}$ fixation of carbonated cement paste samples at 84 days (weight $(\%)$ ).

\begin{tabular}{lccccc}
\hline Parameter & OPC- & $\gamma 5-$ & $\gamma 10-$ & $\gamma 20-$ & $\gamma 40-$ \\
PC & PC & PC & PC & PC \\
\hline $\begin{array}{l}\text { Estimated } \mathrm{CO}_{2} \\
\text { fixation }\end{array}$ & 23.34 & 24.18 & 24.65 & 25.04 & 26.40 \\
\hline
\end{tabular}

TABLe 7: Estimated $\mathrm{CaCO}_{3}$ content of carbonated cement paste samples at 84 days (weight (\%)).

\begin{tabular}{lccccc}
\hline Parameter & $\begin{array}{c}\text { OPC- } \\
\text { PC (\%) }\end{array}$ & $\begin{array}{c}\gamma 5-\mathrm{PC} \\
(\%)\end{array}$ & $\begin{array}{c}\gamma 10-\mathrm{PC} \\
(\%)\end{array}$ & $\begin{array}{c}\gamma 20-\mathrm{PC} \\
(\%)\end{array}$ & $\begin{array}{c}\gamma 40-\mathrm{PC} \\
(\%)\end{array}$ \\
\hline $\begin{array}{l}\text { Estimated } \\
\mathrm{CaCO}_{3} \text { content }\end{array}$ & 53.05 & 54.95 & 56.02 & 56.91 & 60.00 \\
\hline
\end{tabular}

be observed that the diameters of the pores in the noncarbonated sample of OPC-M, $\gamma 10-\mathrm{M}$, and $\gamma 40-\mathrm{M}$ are mainly in the range of approximately $0.08-0.15 \mu \mathrm{m}$. Pores with a diameter smaller than $0.1 \mu \mathrm{m}$ are even more in $\gamma 10-\mathrm{M}$ than in OPC-M, especially those smaller than $0.06 \mu \mathrm{m}$. The porosity above $0.1 \mu \mathrm{m}$ is approximately the same as that of OPC-M. Therefore, it can be inferred that the addition of $\gamma-\mathrm{C}_{2} \mathrm{~S}$ with low substitution leads to an increase in the formation of relatively fine pores $(<0.08 \mu \mathrm{m})$. The pore structure of the $\gamma 40-\mathrm{M}$ noncarbonated sample shows the lowest pore concentration in the range of $0.08-0.15 \mu \mathrm{m}$, and the quantity of other pore sizes increased, especially in the range of $0.01-0.02 \mu \mathrm{m}$ and above $0.15 \mu \mathrm{m}$. The addition of a large amount of $\gamma-\mathrm{C}_{2} \mathrm{~S}$ significantly increases the quantity of large capillary pores. Figure 7 also shows the total porosity of the noncarbonated sample increases as $\gamma-\mathrm{C}_{2} \mathrm{~S}$ increases. The reduction in the total amount of hydration products due to the nonhydraulic characteristic of $\gamma-\mathrm{C}_{2} \mathrm{~S}$ probably results in an increase in porosity.
In Figure 6(b), the pore diameters of the OPC-MC and $\gamma 10$-MC samples were concentrated between 0.1 and $0.2 \mu \mathrm{m}$. $\gamma 40-\mathrm{MC}$ carbonated sample had distinct peak at $0.5 \mu \mathrm{m}$. Overall, the amount of large capillary pores in all three carbonated samples were more than that in uncarbonated samples. This coarsening of the pore structure can be explained by the formation of amorphous $\mathrm{SiO}_{2}$ gel due to the decomposition of C-S-H during carbonation [2, 36, 37]. As seen in Figure 7, total porosity of carbonated samples was significantly less compared to noncarbonated samples. It attributed to the formation of carbonation products which blocked pores, although the relatively larger capillary pore increased.

According to the total porosity results shown in Figure 7, the porosity of the noncarbonated samples of OPC-MC, $\gamma 10-\mathrm{MC}$, and $\gamma 40-\mathrm{MC}$ are $13.9 \%, 16.16 \%$, and $18.79 \%$, respectively. The porosity of the carbonated samples of OPCMC was $11.25 \%$, which is $19.1 \%$ less compared to noncarbonated samples of OPC-MC. For $\gamma 10-\mathrm{MC}$ and $\gamma 40-\mathrm{MC}$, more calcium carbonates were produced due to the addition of $\gamma-\mathrm{C}_{2} \mathrm{~S}$ as shown in TGA results. The total porosity of $\gamma 10$ $\mathrm{MC}$ and $\gamma 40-\mathrm{MC}$ was $22.42 \%$ and $22.97 \%$ less than $\gamma 10-\mathrm{M}$ and $\gamma 40-\mathrm{M}$, respectively. The gaps between porosity of noncarbonated and carbonated samples were more obvious as the replacement ratio increases. Vaterite formed by the carbonation of $\gamma-\mathrm{C}_{2} \mathrm{~S}$ is denser than calcite and aragonite (vaterite: $2.645 \mathrm{~g} / \mathrm{cm}^{3}$, calcite: $2.711 \mathrm{~g} / \mathrm{cm}^{3}$, and aragonite: $2.944 \mathrm{~g} / \mathrm{cm}^{3}$ ) [42]. Thus, volume expansion caused by vaterite and the formation of highly polymerized silica gel result in pores blocking in cement mortar samples incorporating $\gamma-\mathrm{C}_{2} \mathrm{~S}$.

3.5. Carbonation Depth. The carbonation depth at 3, 7, 14, and 28 days after the accelerated carbonation is shown in Figure 8 . 


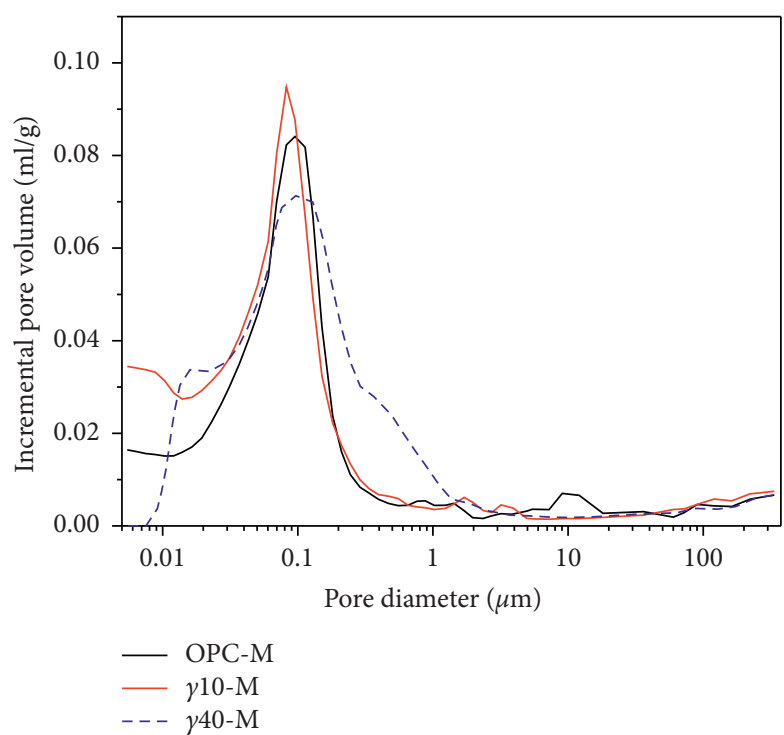

(a)

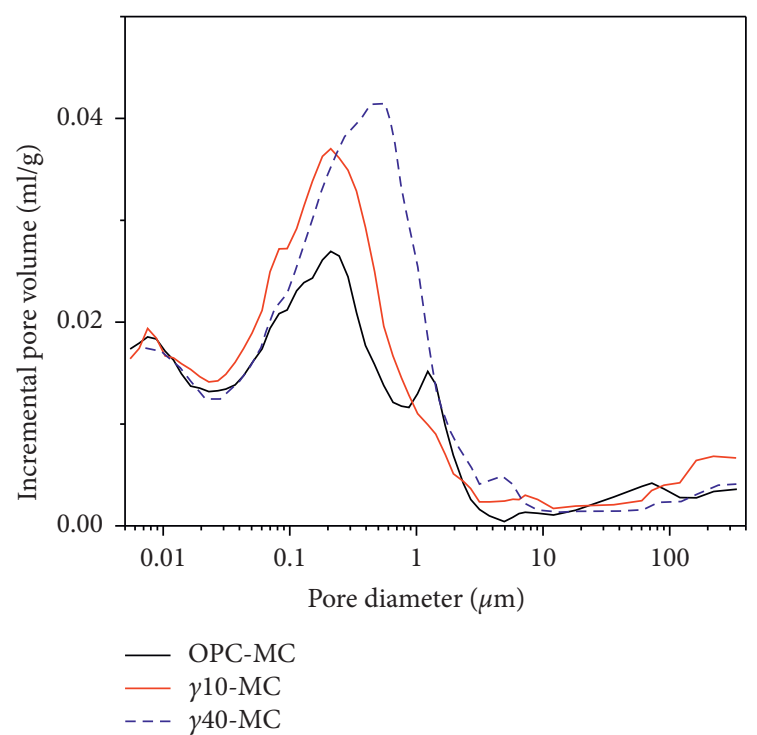

(b)

Figure 6: The pore distribution in noncarbonated and carbonated cement mortar samples at 84 days. (a) The pore distribution in noncarbonated samples (M). (b) The pore distribution in carbonated samples (MC).

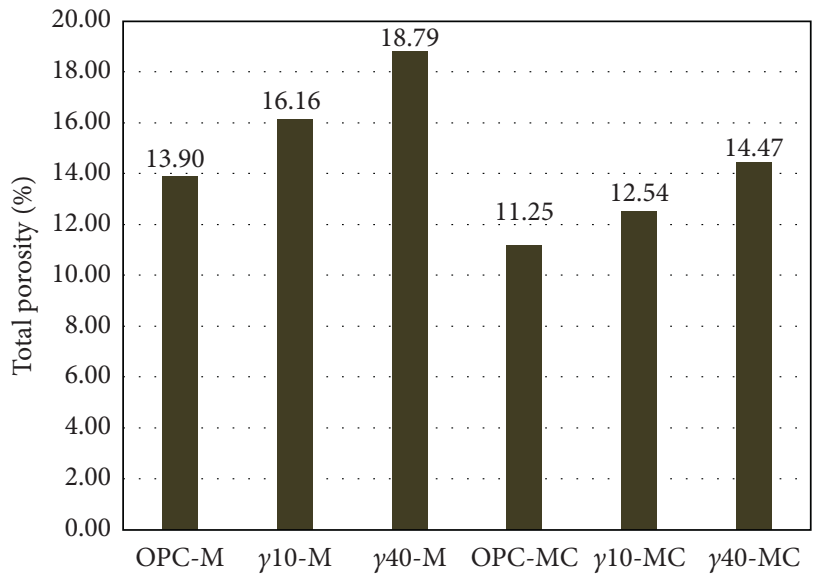

FIGURE 7: The total porosity of noncarbonated (M) and carbonated (MC) cement mortar samples at 84 days.

When the replacement ratio of $\gamma-\mathrm{C}_{2} \mathrm{~S}$ is low $(\gamma 5-\mathrm{MC}$ and $\gamma 10-\mathrm{MC})$, the carbonation depth decreases at all ages as substitution increases. When the substitution ratio reaches at $20 \%$, the carbonation depth begins to increase but is still lower than that of OPC-MC. However, the carbonation depth of $\gamma 40-\mathrm{MC}$ was higher at all ages than that of OPCMC. This is probably due to the dual effects of $\mathrm{CO}_{2}$ sequestration and alkalinity change. For the samples with a low replacement ratio $(\gamma 5-\mathrm{MC}$ and $\gamma 10-\mathrm{MC})$, the addition of $\gamma-\mathrm{C}_{2} \mathrm{~S}$ led to the increased consumption of $\mathrm{CO}_{2}$ in the cement mortar, and then the diffusion rate could be slowed down. Also, the subsequent intrusion channels for $\mathrm{CO}_{2}$ were limited due to the formation of more carbonates. Thus, the diffusion rate simultaneously decreased even further. For the samples with a high replacement ratio $(\gamma 20-\mathrm{MC}$ and $\gamma 40$ $\mathrm{MC})$, the hydration products decreased significantly which led to the decrease in alkalinity of the systems, and then an

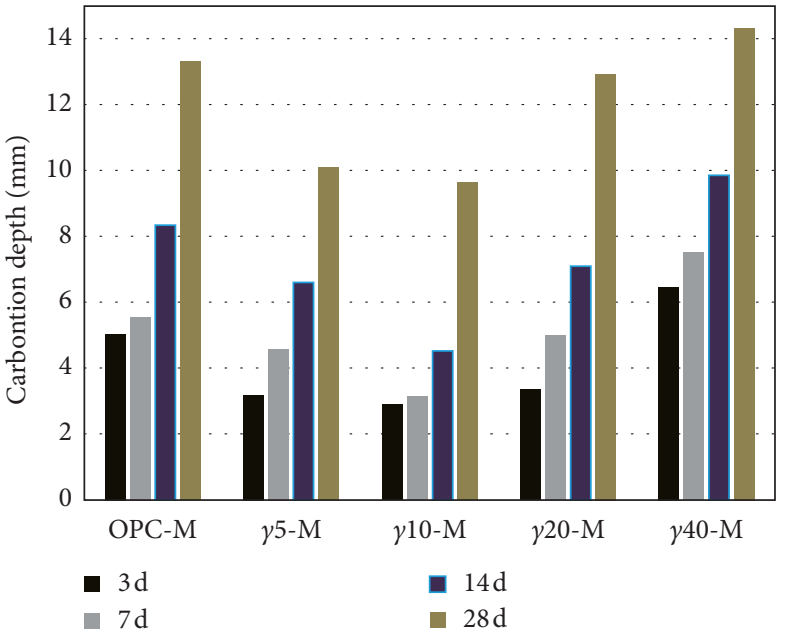

Figure 8: The carbonation depth of cement mortar samples at 3, 7, 14 , and 28 days after the start of the accelerated carbonation.

internal environment of the samples became neutral soon after carbonation started. This phenomenon can be widely observed in cement-based composite materials containing supplementary cementitious materials (SCMs) [2, 4, 25]. Based on experimental results, it is considered that incorporating $\gamma-\mathrm{C}_{2} \mathrm{~S}$ at a low replacement ratio can improve the carbonation resistance of the cement mortar.

\section{Conclusions}

In this study, the carbonation resistance of cement-based composite materials incorporating $0 \%, 5 \%, 10 \%, 20 \%$, and $40 \%$ of $\gamma-\mathrm{C}_{2} \mathrm{~S}$ was evaluated. The feasibility of methods incorporating $\gamma-\mathrm{C}_{2} \mathrm{~S}$ into cement mortar to capture $\mathrm{CO}_{2}$, reduce $\mathrm{CO}_{2}$ diffusion, and improve the pore structure to 
inhibit the carbonation reaction was verified. The main conclusions are as follows:

(1) Calcite, aragonite, and vaterite were the carbonation products formed in the cement paste during the accelerated carbonation. Vaterite is considered the main carbonation product of $\gamma-\mathrm{C}_{2} \mathrm{~S}$, which increased significantly in carbonated cement paste samples containing $40 \% \gamma-\mathrm{C}_{2} \mathrm{~S}$.

(2) In the DSC-TG study, the mass loss between $500^{\circ} \mathrm{C}-850^{\circ} \mathrm{C}$ is associated with the decomposition of crystallized and amorphous calcium carbonate. The results show that the $\mathrm{CaCO}_{3}$ content and amount of $\mathrm{CO}_{2}$ fixation increased with increasing replacement of $\gamma-\mathrm{C}_{2} \mathrm{~S}$.

(3) The porosity of the noncarbonated cement mortar increased as the substitution of $\gamma-\mathrm{C}_{2} \mathrm{~S}$ increased, which was caused by the relatively low hydration degree due to the dilution effect of $\gamma-\mathrm{C}_{2} \mathrm{~S}$ replacement. The porosity of the carbonated cement mortar was less than noncarbonated samples due to the formation of carbonates in the capillary pores. The carbonation products of $\gamma-\mathrm{C}_{2} \mathrm{~S}$ are mainly vaterite and highly polymerized silica gel which could block the pores off effectively and limit the diffusion of $\mathrm{CO}_{2}$ into the system.

(4) For the samples with a low replacement ratio $(\gamma 5$ $\mathrm{MC}$ and $\gamma 10-\mathrm{MC})$, the carbonation depth shows a downward trend at all ages with the increase in replacement rate, and $\gamma 10-\mathrm{MC}$ had the lowest carbonation depth. However, porosity was increased and susceptibility to carbonation was increased with further increase in replacement rate of $\gamma-\mathrm{C}_{2} \mathrm{~S}$. The carbonation depth began to increase with more than $20 \%$ replacement of cement with $\gamma-\mathrm{C}_{2}$ S. The carbonation depth of $\gamma 40$-MC was higher than that of OPC-MC at all ages. The experimental results revealed that the incorporation of $\gamma-\mathrm{C}_{2} \mathrm{~S}$ at a lower substitution rate can improve the carbonation resistance of the cement mortar.

\section{Data Availability}

The data used to support the findings of this study are available from the corresponding author upon request.

\section{Conflicts of Interest}

The authors declare that they have no conflicts of interest.

\section{Authors' Contributions}

Zhengxin Chen and Hanseung Lee conceptualized the study; Zhengxin Chen and Yunsu Lee performed the experiments and analyzed the data; Hyeongkyu Cho synthesized $\gamma-C_{2} S$; Zhengxin Chen prepared the original draft; Seungmin Lim reviewed and edited the manuscript; and Hanseung Lee supervised the research.

\section{Acknowledgments}

This research was supported by a grant (19SCIP-B103706-05) from the Construction Technology Research Program funded by the Ministry of Land, Infrastructure and Transport of Korean Government.

\section{References}

[1] C. Shi, M. Liu, P. He, and Z. Ou, "Factors affecting kinetics of $\mathrm{CO}_{2}$ curing of concrete," Journal of Sustainable Cement-Based Materials, vol. 1, no. 1-2, pp. 24-33, 2012.

[2] W. Ashraf, "Carbonation of cement-based materials: challenges and opportunities," Construction and Building Materials, vol. 120, pp. 558-570, 2016.

[3] H.-S. Lee and X.-Y. Wang, "Evaluation of the carbon dioxide uptake of slag-blended concrete structures, considering the effect of carbonation," Sustainability, vol. 8, no. 4, pp. 312329, 2016.

[4] B. Šavija and M. Lukovićb, "Carbonation of cement paste: understanding, challenges, and opportunities," Construction and Building Materials, vol. 117, pp. 285-301, 2016.

[5] M. A. Aguirre-Guerrero and R. M. De Gutiérrez, "13-assessment of corrosion protection methods for reinforced concrete," in Eco-Efficient Repair and Rehabilitation of Concrete Infrastructures, F. Pacheco-Torgal, E. R. Melchers, X. Shi et al., Eds., pp. 315-353, Woodhead Publishing, Cambridge, UK, 1st edition, 2018.

[6] X. Pan, Z. Shi, C. Shi, T.-C. Ling, and N. Li, "A review on concrete surface treatment part I: types and mechanisms," Construction and Building Materials, vol. 132, pp. 578-590, 2017.

[7] L. Shi, J. Liu, and J. Liu, "Effect of polymer coating on the properties of surface layer concrete," Procedia Engineering, vol. 27, pp. 291-300, 2012.

[8] W. Tsao, M. Liang, J. Chang, and N. Huang, "Effect of mortar coating on concrete carbonation," Journal of Marine Science and Technology, vol. 23, pp. 420-430, 2015.

[9] M. A. Baccay, N. Otsuki, T. Nishida, and S. Maruyama, "Influence of cement type and temperature on the rate of corrosion of steel in concrete exposed to carbonation," Corrosion Engineering, vol. 62, no. 9, pp. 811-821, 2006.

[10] Y. Mu, Z. Liu, F. Wang, and X. Huang, "Carbonation characteristics of $\gamma$-dicalcium silicate for low-carbon building material," Construction and Building Materials, vol. 177, pp. 322-331, 2018.

[11] K. Saphouvong, T. Saito, N. Otsuki, and T. Yumoto, "Corrosion of steel bars in autoclaved concrete pile containing $\gamma-2 \mathrm{CaO} \cdot \mathrm{SiO}_{2}$ with an accelerated carbonation curing submerged in the real marine environment," Journal of the Society of Materials Science, Japan, vol. 61, no. 3, pp. 299-307, 2012.

[12] Y. Mu, G. Xue, S. Zhao, X. Huang, and F. Wang, "Development of carbonation of $\gamma$-dicalcium silicate," Journal of the Chinese Ceramic Society, vol. 45, pp. 1198-1203, 2017.

[13] H. Béarat, M. J. McKelvy, A. V. G. Chizmeshya et al., "Carbon sequestration via aqueous olivine mineral carbonation: role of passivating layer formation," Environmental Science \& Technology, vol. 40, no. 15, pp. 4802-4808, 2006.

[14] Q. Wang, H. Manzano, Y. Guo, I. Lopez-Arbeloa, and $\mathrm{X}$. Shen, "Hydration mechanism of reactive and passive dicalcium silicate polymorphs from molecular simulations," The Journal of Physical Chemistry C, vol. 119, no. 34, pp. 19869-19875, 2015. 
[15] X. Guan, S. Liu, C. Feng, and M. Qiu, "The hardening behavior of $\gamma-\mathrm{C}_{2} \mathrm{~S}$ binder using accelerated carbonation," Construction and Building Materials, vol. 114, pp. 204-207, 2016.

[16] R. L. Berger, J. F. Young, and K. Leung, "Acceleration of hydration of calcium silicates by carbon dioxide treatment," Nature Physical Science, vol. 240, no. 97, pp. 16-18, 1972.

[17] S. Kerisi, E. J. Bylaska, and A. R. Felmy, "Water and carbon dioxide adsorption at olivine surfaces," Chemical Geology, vol. 359, pp. 81-89, 2013.

[18] T. Saito, E. Sakai, M. Morioka, and N. Otsuki, "Carbonation of $\gamma-\mathrm{Ca}_{2} \mathrm{SiO}_{4}$ and the mechanism of vaterite formation," Journal of Advanced Concrete Technology, vol. 8, no. 3, pp. 273-280, 2010.

[19] T. Higuchi, M. Morioka, I. Yoshioka, and K. Yokozeki, "Development of a new ecological concrete with $\mathrm{CO}_{2}$ emissions below zero," Construction and Building Materials, vol. 67, pp. 338-343, 2014.

[20] M. Morioka, K. Yamamoto, T. Torichigai, and K. Yokozeki, "Manufacturing of $\gamma-\mathrm{C}_{2} \mathrm{~S}$ used by industrial raw material and its evaluation of $\mathrm{CO}_{2}$ emission," Cement Science and Concrete Technology, vol. 64, no. 1, pp. 29-34, 2010.

[21] K. Watanabe, K. Yokozeki, R. Ashizawa et al., "High durability cementitious material with mineral admixtures and carbonation curing," Waste Management, vol. 26, no. 7, pp. 752-757, 2006.

[22] J. Wang, F. Zhang, J. Zhang, R. C. Ewing, U. Becker, and Z. Cai, "Carbonate orientational order and superlattice structure in vaterite," Journal of Crystal Growth, vol. 407, pp. 78-86, 2014.

[23] S. Udagawa, K. Urabe, M. Natsume, and T. Yano, "Refinement of the crystal structure of $\gamma-\mathrm{Ca}_{2} \mathrm{SiO}_{4}$," Cement and Concrete Research, vol. 10, no. 2, pp. 139-144, 1980.

[24] J. Chang, Y. Fang, and X. Shang, "The role of $\beta-C_{2} S$ and $\gamma-C_{2} S$ in carbon capture and strength development," Materials and Structures, vol. 49, no. 10, pp. 4417-4424, 2016.

[25] B. Lu, C. Shi, and G. Hou, "Strength and microstructure of $\mathrm{CO}_{2}$ cured low-calcium clinker," Construction and Building Materials, vol. 188, pp. 417-423, 2018.

[26] S. Gopi, V. K. Subramanian, and K. Palanisamy, "Aragonitecalcite-vaterite: a temperature influenced sequential polymorphic transformation of $\mathrm{CaCO}_{3}$ in the presence of DTPA," Materials Research Bulletin, vol. 48, no. 5, pp. 1906-1912, 2013.

[27] D. Chakrabarty and S. Mahapatra, "Aragonite crystals with unconventional morphologies," Journal of Materials Chemistry, vol. 9, no. 11, pp. 2953-2957, 1999.

[28] E. Mohamed, S. Ismaiel, H. Hanaa, and L. R. Abdel, "Preparation of vaterite calcium carbonate in the form of spherical nano-size particles with the aid of polycarboxylate superplasticizer as a capping agent," American Journal of Nanomaterials, vol. 4, pp. 44-51, 2016.

[29] T. Siva, S. Muralidharan, S. Sathiyanarayanan, E. Manikandan, and M. Jayachandran, "Enhanced polymer induced precipitation of polymorphous in calcium carbonate: calcite aragonite vaterite phases," Journal of Inorganic and Organometallic Polymers and Materials, vol. 27, no. 3, pp. 770-778, 2017.

[30] K. Naka, Y. Tanaka, and Y. Chujo, "Effect of anionic starburst dendrimers on the crystallization of $\mathrm{CaCO}_{3}$ in aqueous solution: size control of spherical vaterite particles," Langmuir, vol. 18, no. 9, pp. 3655-3658, 2002.

[31] C. Zhu, Y. Fang, and H. Wei, "Carbonation-cementation of recycled hardened cement paste powder," Construction and Building Materials, vol. 192, pp. 224-232, 2018.
[32] S. A. Bernal, R. M. De Gutierrez, J. L. Provis, and V. Rose, "Effect of silicate modulus and metakaolin incorporation on the carbonation of alkali silicate-activated slags," Cement and Concrete Research, vol. 40, no. 6, pp. 898-907, 2010.

[33] M. Nedeljković, Y. Zuo, K. Arbi, and G. Ye, "Carbonation resistance of alkali-activated slag under natural and accelerated conditions," Journal of Sustainable Metallurgy, vol. 4, no. 1, pp. 33-49, 2018.

[34] X. Pan, Z. Shi, C. Shi, X. Hu, and L. Wu, "Interactions between inorganic surface treatment agents and matrix of Portland cement-based materials," Construction and Building Materials, vol. 113, pp. 721-731, 2016.

[35] P. He, C. Shi, Z. Tu, C. S. Poon, and J. Zhang, "Effect of further water curing on compressive strength and microstructure of $\mathrm{CO}_{2}$-cured concrete," Cement and Concrete Composites, vol. 72, pp. 80-88, 2016.

[36] M. Thiéry, P. Faure, A. Morandeau et al., "Effect of carbonation on the microstructure and moisture properties of cement-based materials," in Proceedings of the 12th International Conference on Building Materials and Components, Porto, Portugal, April 2011.

[37] A. Morandeau, M. Thiéry, and P. Dangla, "Impact of accelerated carbonation on OPC cement paste blended with fly ash," Cement and Concrete Research, vol. 67, pp. 226-236, 2015.

[38] C. Ghoroi, D. Venkateswaran, and A. K. Suresh, “A critique of thermokinetic analysis in solids processing: cement industry as a case study," Thermochimica Acta, vol. 618, pp. 56-66, 2015.

[39] A. Z. Morshed and Y. Shao, "Influence of moisture content on $\mathrm{CO}_{2}$ uptake in lightweight concrete subject to early carbonation," Journal of Sustainable Cement-Based Materials, vol. 2, no. 2, pp. 144-160, 2013.

[40] A. Hidalgo, C. Domingo, C. Garcia, S. Petit, C. Andrade, and C. Alonso, "Microstructural changes induced in Portland cement-based materials due to natural and supercritical carbonation," Journal of Materials Science, vol. 43, no. 9, pp. 3101-3111, 2008.

[41] S. Lim and P. Mondal, "Effects of incorporating nanosilica on carbonation of cement paste," Journal of Materials Science, vol. 50, no. 10, pp. 3531-3540, 2015.

[42] T. Saito, E. Sakai, M. Morioka, and M. Daimon, "Carbonation reaction of calcium silicate hydrates by hydrothermal synthesis at $150^{\circ} \mathrm{C}$ in OPC- $\gamma$ - $\mathrm{Ca}_{2} \mathrm{SiO}_{4}-\alpha$-Quartz systems," Journal of Advanced Concrete Technology, vol. 5, no. 3, pp. 333-341, 2007. 


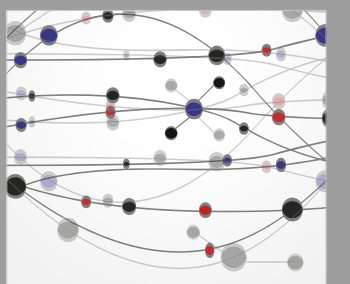

The Scientific World Journal
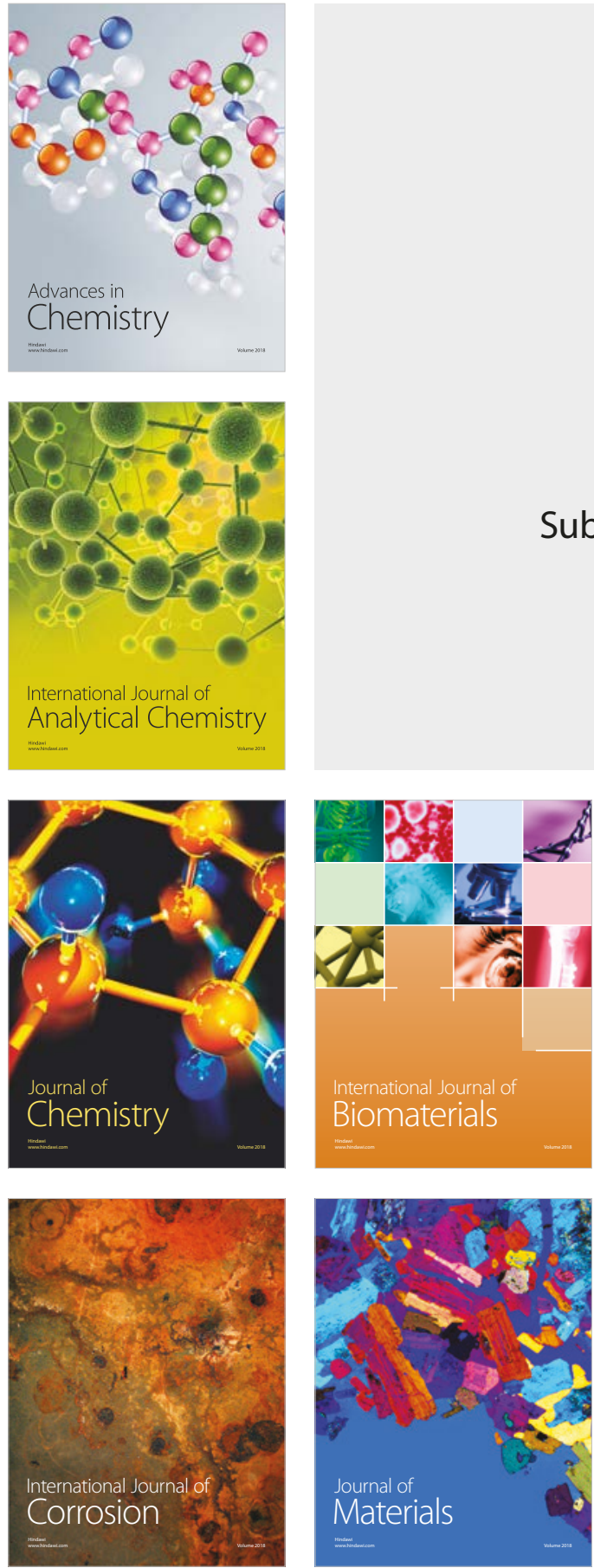

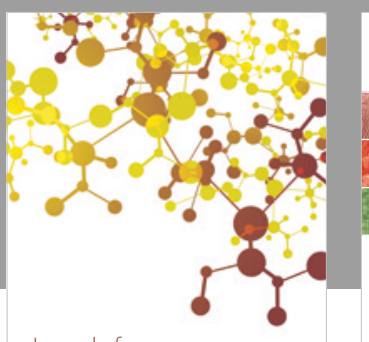

Journal of

Applied Chemistry
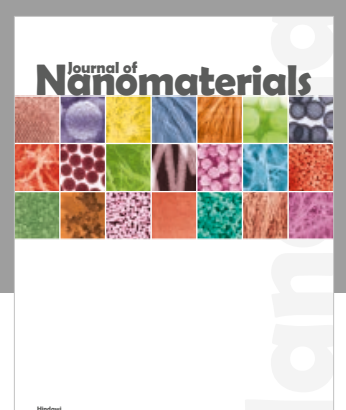

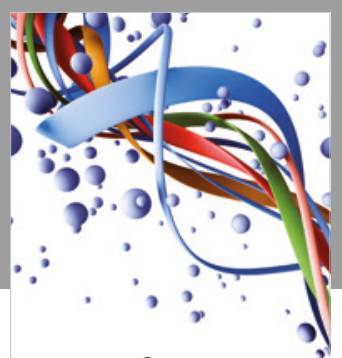

Scientifica

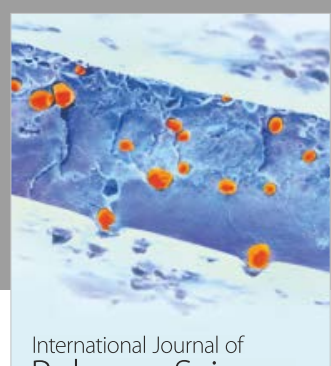

Polymer Science

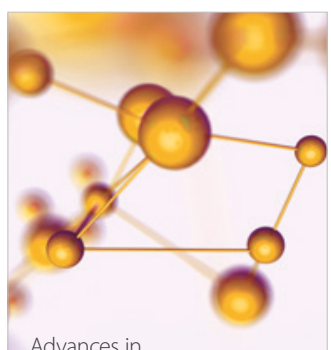

Physical Chemistry
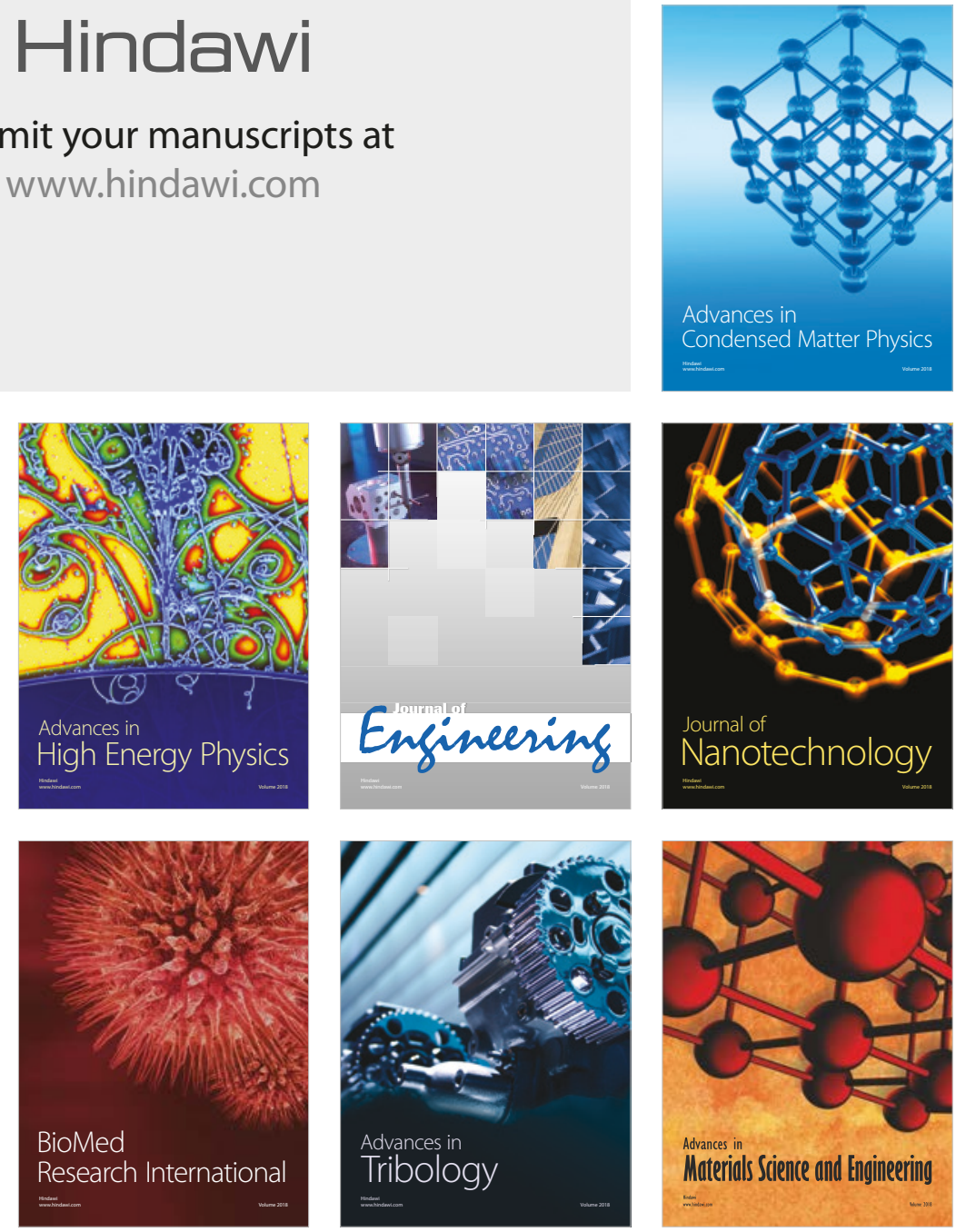